\title{
Third Ventricle Herniation into the Sphenoid Sinus Following Endoscopic Transnasal Transsphenoidal Fenestration of Rathke's Cleft Cyst
}

\author{
Ratbke Yarığı Kistinin Endoskopik Transnazal Transsfenoidal \\ Fenestrasyonu Sonrasında Üçüncü Ventrikülün Sfenoid Sinüse \\ Herniasyonu
}

\author{
Maryam JALESSI $^{1}$, Guive SHARIFI ${ }^{2}$, Amin JAHANBAKHSHI ${ }^{2}$, Khosro PARSA ${ }^{3}$, Parin YAZDANIFARD ${ }^{1}$ \\ ${ }_{1}^{1}$ Iran University of Medical Sciences, Hazrat Rasoul Akram Hospital, Endoscopic Pituitary and Skull Base Surgery Unit, ENT-Head and Neck \\ Research Center and Department, Tehran, Islamic Republic of Iran \\ ${ }^{2}$ Shaheed Beheshti University of Medical Sciences, Loghman Hakim Hospital, Department of Neurosurgery, Tehran, Islamic Republic of Iran \\ ${ }^{3}$ Iran Mehr Hospital, Department of Neurosurgery, Tehran, Islamic Republic of Iran
}

Corresponding Author: Guive SHARIFI / E-mail: gsharifimd@gmail.com

\begin{abstract}
Rathke cleft cyst (RCC) is an uncommon albeit benign sellar lesion with an incidence rate of between 2 to $33 \%$. RCCs are usually asymptomatic except in the large cases whit suprasellar extension. We herein describe a unique case of RCC, which presented with severe visual loss owing to massive herniation of the optic chiasm and third ventricle down into the sphenoid sinus through a small $8 \times 8$ mm foramen after transnasal endoscopic surgical fenestration and marsupialization of the cyst. We describe a reconstruction method via endonasal transsphenoidal approach in this case and suggest prophylactic reconstruction of the sellar floor in sellar lesions with equal or more voluminous suprasellar extensions that are susceptible to such massive herniation and secondary empty sella syndrome.
\end{abstract}

KEYWORDS: Rathke cleft cysts, Sella turcica, Secondary empty sella syndrome

öz

Rathke yarığı kisti nadir ve benign bir sellar lezyon olup insidansı \%2 ila 33 arasındadır. Rathke yarığı kistleri genellikle suprasellar uzantılı büyük olgular dışında asemptomatiktir. Burada optik kiazm ve üçüncü ventrikülün transnazal endoskopik cerrahi ile fenestrasyon ve kist marsüpializasyonundan sonra küçük $8 \times 8 \mathrm{~mm}$ bir foramen içinden sfenoid sinüse masif herniasyonu nedeniyle şiddetli görme kaybıyla gelen benzersiz bir Rathke yarığı kisti olgusu sunuyoruz. Bu olguda endonazal transsfenoidal yaklaşımla bir rekonstrüksiyon yöntemi öneriyor ve bu tür masif herniasyon ve sekonder boş sella sendromuna yatkın olan eşit derecede veya daha hacimli suprasellar uzantılara sahip sellar lezyonlarda, sella tabanının profilaktik olarak rekonstrüksiyonunu öneriyoruz.

ANAHTAR SÖZCÜKLER: Rathke yarığı kistleri, Sella tursika, Sekonder boş sella sendromu

\section{INTRODUCTION}

Persistence of an embryonic Rathke cleft, which appears during the third or fourth week of embryonic life and usually disappears in the eleventh week, may result in the formation of a benign cyst in the sellar region named Rathke's cleft cyst (RCC) $(7,13,14)$. RCCs usually present in the 4 th to 5 th decades of life and are typically located in the sella, with suprasellar extension in more than half of the cases, and with an incidence rate of 2 to $33 \%$ in autopsy reports $(12,13,14,15,21)$. Most RCCs are asymptomatic, except for the large cysts that can exert pressure on the surrounding structures comprising the pituitary gland and chiasm, and present with headache, visual defects and endocrinopathies. In these symptomatic cases, surgical treatment seems inevitable and the most accepted surgical approach is transnasal transsphenoid surgery for total cyst removal or marsupialization of the cyst. Herein, we introduce an operated RCC case, presented with severe loss of vision due to severe herniation of the optic chiasm and third ventricle down into the sphenoid sinus after transnasal endoscopic fenestration of the RCC. The presented case is unique because of the extent of herniation (into the sphenoid sinus) through a small foramen of $8 \times 8 \mathrm{~mm}$ following cyst marsupialization. The probable causes of this complication, surgical intervention for reduction of the herniated structures, and the reconstruction technique of the skull base defect are discussed.

\section{CASE REPORT}

An 8-year-old girl was referred to our hospital for recurrence 
of her symptoms after several surgeries performed for RCC. Her problems began at the age of three, with occasional falling attacks. The pathology was not diagnosed until she was five; her symptoms comprised headaches, nausea, vomiting, and drowsiness. Following complete clinical, laboratory and imaging investigations, and with the diagnosis of a sellar cystic lesion with suprasellar extension, she underwent a transcranial surgery at the age of six. Pathologic assessment revealed that the lesion was RCC. One year later, with the suspicion of recurrent RCC due to her suffering from the same symptoms, she underwent a conventional microscopic transsphenoid surgery to remove the regrowth lesion. Two years later, she was referred to our center with bitemporal visual field defects, diabetes insipidus (DI) and growth retardation. Imaging studies showed recurrent sellar and suprasellar RCC, compressing the chiasm (Figure 1A, B). We scheduled an endoscopic endonasal transsphenoid approach to better investigate the region and remove the regrown cyst. After introducing the endoscope, the cyst was fenestrated to empty the content. Some parts of the cyst walls severely adhered to the arachnoid and chiasm. Therefore, only the inferior and lateral parts of the cyst walls were resected and the superior part left intact. Since there was no evidence of an intraoperative CSF leak and mild arachnoid drop to the sellar area, we did not reconstruct the sellar floor to prevent any recurrence. Postoperatively, her visual field improved, although some bitemporal defects remained. After 8 months, she came back with a sudden vision loss that had been going on for a week and was deteriorating quickly. Visual acuity of both eyes was just at the level of light perception, and the perimetry test showed severe loss of visual fields. MRI showed a severely prolapsed optic chiasm and third ventricle into the sphenoid sinus through an $8 \times 8 \mathrm{~mm}$ sellar floor defect (Figure 1C, D). Another endoscopic transsphenoid approach was urgently planned; after introducing the endoscope, herniated tissues showed up in the sphenoid sinus touching the rim of previous sphenoidotomy. In order to reduce the herniated tissue without violation, a reservoir of a ventriculoperitoneal (VP) shunt was used as a cushion and gentle pressure was applied on it. By this manouver, complete reduction of the hernia at the sellar floor level could be achieved. The reservoir of VP shunt was placed underlay to the bone as a barrier. It had been previously perforated at the center to facilitate the drainage of the remaining cyst wall secretions and reduce the risk of recurrent cyst formation. Subsequently, it was buttressed by two titanium plates, which crossed each other and were screwed to the remnant of the sphenoid bone rostrum (Figure 1E).

Postoperatively, the girl's vision improved so quickly that in the recovery room she commented on it. A follow-up MRI at postoperative month 6 (Figure 1F) revealed no sign of new herniation or any other complications, and the lumbar puncture measured normal CSF pressure of $18 \mathrm{cmH}_{2} \mathrm{O}$. After two years, she is still symptom-free and receives a regular follow up program. Post-operative nasal endoscopy and imaging studies verify that this technique was successful.

\section{DISCUSSION}

Secondary empty sella syndrome is described as empty sella following pharmacotherapy, radiotherapy or surgery of sellar pathologies. It is also a rare, albeit imperative, complication of RCC surgeries as was first described by Fischer in 1994 $(6,8)$. It may result from a brain tumor, intracranial pressure, inflammation in the area, or traction of scar tissue between the suprasellar structures and the diaphragma sellae or wall of the cyst, pulling them down into the sella $(3,6,8,10,11$, 19). Other than the empty sella syndrome, a relatively high recurrence rate is another complication of RCC surgeries. Aho and colleagues (1) reported a five-year, $18 \%$ recurrence rate of RCC following surgery.

Partial removal of the cyst wall is the first suggested surgical choice in RCCs, but in multiple recurrent cases, total removal of the cyst wall is recommended to reduce the rate of recurrence despite the increasing risk of a CSF leak (21). However, in revision case adherence of the wall to adjacent structures may put these structures in danger during total removal of the cyst wall. In our case, the cyst critically adhered to the chiasm because of multiple recurrences, and prevented us from removing the cyst wall totally. We decided to resect the cyst wall partially and leave the posterior part intact to prevent violation of the arachnoid, a subsequent CSF leak and obligatory reconstruction of the sellar floor.

Simple closure or reconstruction of the sellar floor using grafts is a challenging issue in transsphenoidal surgery. This was considered to be an essential part of the procedure regardless of the presence or absence of a CSF leak (1618), although recent data support that there is no need to reconstruct the bony defect of sella when there is no intraoperative CSF leak $(2,5,9,4)$. Adopting this discipline especially in the case of RCCs could help in drainage of the cyst secretion and reduce the risk of recurrence therefore the sellar reconstruction is not recommended in cases of RCCs without intraoperative CSF leak (21). Based on this strategy and our experience with not reconstructing the bony floor of sella in endoscopic transsphenoidal approach for pituitary adenoma, RCC and even craniopharyngiomas, we did not reconstruct the defective sellar floor $(8 \times 8 \mathrm{~mm})$ in this case, since there was no evidence of a CSF leak intraoperatively. However, we encountered a secondary empty sella syndrome and herniation of the chiasm and third ventricle that were unexpectedly passing the sella through the $(8 \times 8 \mathrm{~mm})$ bony defect, as far as the anterior wall of the sphenoid sinus.

The possible reasons for the rare phenomenon encountered in our case would be an intracranial pressure or hydrocephalus as reported by Kassam (3). However, pre- and post-operative imaging studies were not in favor of hydrocephalus, and postoperative CSF pressure was $18 \mathrm{cmH} 2 \mathrm{O}$, which precludes those mechanisms as an explanation.

In order to describe the possible etiology, we focused on the theory of flaccid diaphragma sellae. Large volume sellar tumors with suprasellar extension or any pathology that 


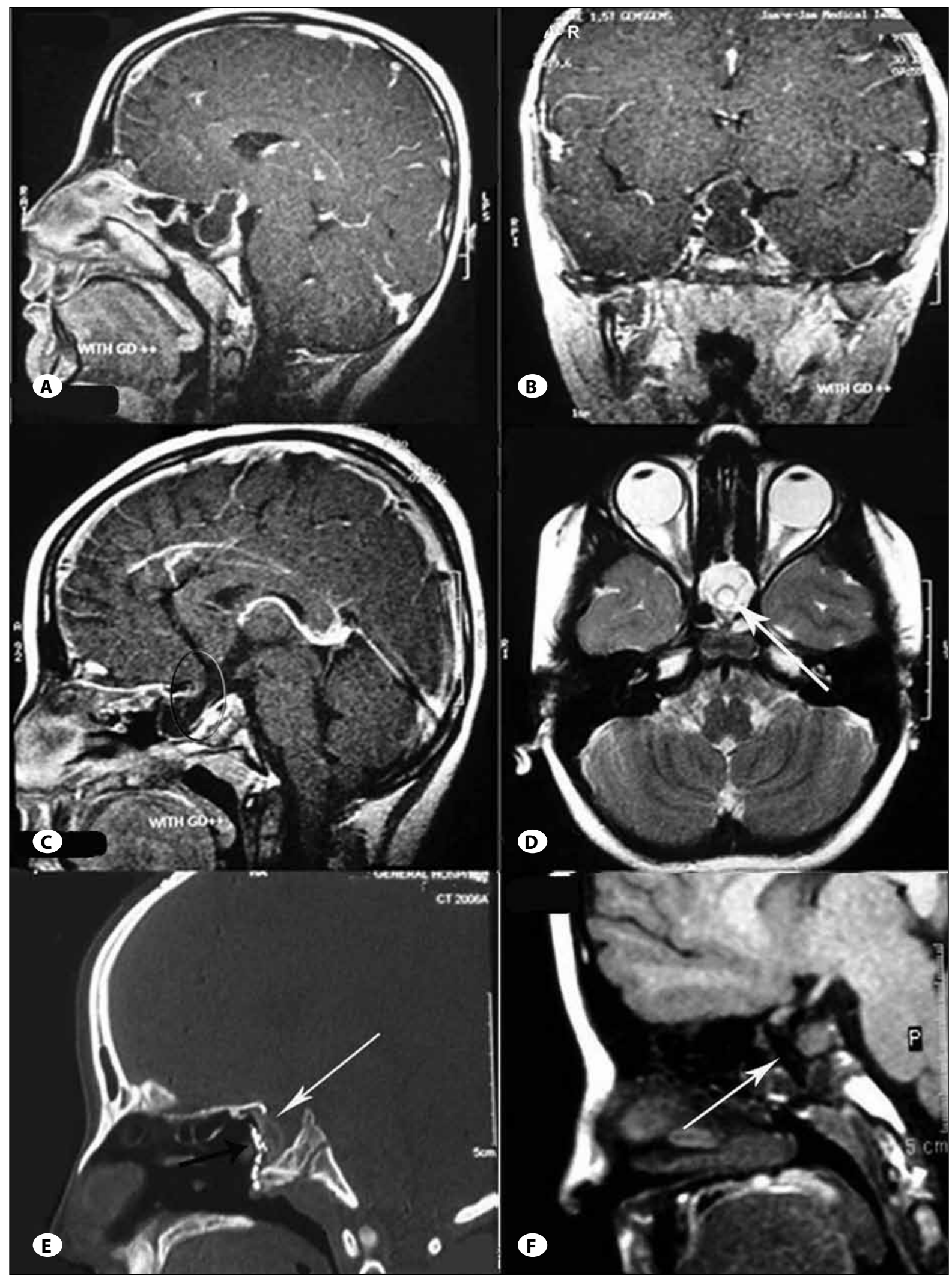

Figure 1: (A, B) Preoperative brain MRI; (T1W) Rathke's cyst with its suprasellar component. Post-first operation MRI; circle in T1weighted (C) and white arrow in T2-weighted (D) views show herniated third ventricle in to the sphenoid sinus. Post-second operation CT scan (E) shows reconstructed sellar floor with titanium plate (black arrow) and shunt reservoir (white arrow), MRI T1-weighted (F) shows reduced optic chiasm herniation (arrow). 
could exert pressure on the diaphragma sella resulting in a reduction of its thickness strength and increase in its length, producing a long flaccid diaphragm that could easily be herniated because of CSF pressure and drag the adhered structures by itself $(10,11,20)$. However, Cappabianca mentioned that some kind of reconstruction might be required in case of prolapse of the suprasellar cistern toward the sellar floor (2). We believe that this etiology along with the presence of severe scar tissue between the cyst wall and supra-arachnoid structures may be alternative explanations of this severe herniation. In view of this, we presume cases of sellar lesions with equal or more voluminous suprasellar extension are susceptible to such massive herniation and are better to be reconstructed prophylactically. It might be better to reconstruct using a cribriform rigid graft that could also help drainage of the cyst secretion and decrease the risk of recurrence of the cyst.

\section{REFERENCES}

1. Aho CJ, Liu C, Zelman V, Couldwell WT, Weiss MH: Surgical outcomes in 118 patients with Rathke cleft cysts. J Neurosurg 102:189-93, 2005

2. Cappabianca P, Cavallo LM, Esposito F, Valente V, De Divitiis E: Sellar repair in endoscopic endonasal transsphenoidal surgery: Results of 170 cases. Neurosurgery 51:1365-1371, 2002

3. Carrau RL, Snyderman CH, Kassam AB: The management of cerebrospinal fluid leaks in patients at risk for high-pressure hydrocephalus. Laryngoscope 115: 205-212, 2005

4. Couldwell WT, Kan P, Weiss MH: Simple closure following transsphenoidal surgery. Technical note. Neurosurg Focus 20: E11, 2006

5. Esposito F, Dusick JR, Fatemi N, Kelly DF: Graded repair of cranial base defects and cerebrospinal fluid leaks in transsphenoidal surgery. Neurosurgery 60 (4 Suppl 2): 295-303, 2007

6. Fischer EG, DeGirolami U, Suojanen JN: Reversible visual deficit following debulking of a Rathke's cleft cyst: A tethered chiasm? J Neurosurg 81:459-462, 1994

7. Gupta V, Grossman A, Kapadia A, Thorat K: Acromegaly associated with a symptomatic Rathke's cyst. Indian J Endocrinol Metab 15:140-142, 2011

8. Kaufman B, Tomsak RL, Kaufman BA, Arafah BU, Bellon EM, Selman WR, Modic MT: Herniation of the suprasellar visual system and third ventricle into empty sellae: Morphologic and clinical considerations. AJR 152: 597-608, 1989
9. Kelly DF, Oskouian RJ, Fineman I: Collagen sponge repair of small cerebrospinal fluid leaks obviates tissue grafts and cerebrospinal fluid diversion after pituitary surgery. Neurosurgery 49: 885-890, 2001

10. Keyaki A, Makita Y, Nabeshima S, Motomochi M, Itagaki T, Tei T: Secondary empty sella syndrome: Report of three cases and review of the literature. No Shinkei Geka 10(11): 1189-1194, 1982

11. Kim JH, Ko JH, Kim HW, Ha HG, Jung CK: Analysis of empty sella secondary to the brain tumors. J Korean Neurosurg Soc 46:355-359, 2009

12. Madhok R, Prevedello DM, Gardner P, Carrau RL, Snyderman $\mathrm{CH}$, Kassam AB: Endoscopic endonasal resection of Rathke cleft cysts: Clinical outcomes and surgical nuances. J Neurosurg 112:1333-1339, 2010

13. Osborn AG, Preece MT: Intracranial cysts: Radiologicpathologic correlation and imaging approach. Radiology 239:650-664, 2006

14. Potts MB, Jahangiri A, Lamborn KR, Blevins LS, Kunwar S, Aghi MK: Suprasellar Rathke cleft cysts: Clinical presentation and treatment outcomes. Neurosurgery 69:1058-1068, 2011

15. Raghunath A, Sampath S, Devi BI, Chandramouli BA, Lal GJ, Chickabasaviah YT, Bharath RD: Is there a need to diagnose Rathke's cleft cyst preoperatively? Neurol India 58:69-73, 2010

16. Raquet F, Mann WJ: Lumbar cerebrospinal fluid drainage for prevention of CSF leak HNO 41: 335- 338, 1993

17. Seda L, Camara RB, Cukiert A, Burattini JA, Mariani PP: Sellar floor reconstruction after transsphenoidal surgery using fibrin glue without grafting or implants: Technical note. Surg Neurol 66: 46-49, 2006

18. Shapiro SA, Scully T: Closed continuous drainage of cerebrospinal fluid via a lumbar subarachnoid catheter for treatment or prevention of cranial/spinal cerebrospinal fluid leak. Neurosurgery 30: 241-245, 1992

19. Thome C, Zevgaridis D. Delayed visual deterioration after pituitary surgery--a review introducing the concept of vascular compression of the optic pathways. Acta Neurochir (Wien) 146:1131-1135, 2004

20. Yuh WT, Zhu M, Taoka T, Quets JP, Maley JE, Muhonen MG, Schuster ME, Kardon RH: MR imaging of pituitary morphology in idiopathic intracranial hypertension. J Magn Reson Imaging 12: 808-813, 2000

21. Zada G: Rathke cleft cysts: A review of clinical and surgical management. Neurosurg Focus 31: E1, 2011 